American Journal of Economics and Business Administration 1 (2): 141-149, 2009

ISSN 1945-5488

(C) 2009 Science Publications

\title{
Determinants of Non-farm Income Diversification in Developed Villages of Bangladesh
}

\author{
${ }^{1}$ Mohammad Abdul Malek and ${ }^{2}$ Koichi Usami \\ ${ }^{1}$ Division of Managerial Economics, The United Graduate School of Agricultural Sciences, \\ Tottori University, Tottori, Japan \\ ${ }^{2}$ Department of Biological and Environmental Sciences, Faculty of Agriculture, \\ Yamaguchi University, Yamaguchi, Japan
}

\begin{abstract}
Problem statement: Though the Non-Farm Sector (NFS) has been prioritized in the national policy documents, empirical evidences based on the broader definition of the sector seem to be insufficient about its role both in income diversification and income distribution especially in segmented area of rural Bangladesh. Approach: We use income inequality Gini decomposition method for exploring the role of Non-Farm Incomes (NFIs) and censored Tobit regression for estimating determinants of NFI diversification. We use original data collected from a field survey on individual participation in farm and Non-Farm Activities (NFAs), labor time and household incomes of 214 randomly selected households in four villages of a typical developed rural area, namely, Comilla Sadar Upazila (Sub-district), for the year 2005-06. Results: The NFAs are undoubtedly no longer "marginal" in the case study villages. In addition to supporting the fact that despite having the greater role of the NFS in income diversification and increasing household income, the NFI components do very little or nothing to reduce income inequality, our Gini-decomposition results suggest that further unevenly access to local high return non-farm self-employments and out-country remittance employments would actually aggravate the income distribution. In addition to local NFS, our econometric results give us several important insights for non-local remittance (out-country) and other incomes (transfers): Lower extent of local high-return Household Non-Farm Enterprises (HNFEs) is a reality and landholding is crucially important for financing such HNFEs. For high-return non-farm wage employments and out-country remittance incomes, where the low-income households have limited access, education is particularly important. Participation of female in direct economic activities is negligible. Social capital and local institutions are not significantly active in promoting either local or non-local NFS. Conclusion/recommendations: The future NFS development strategy, thus, should be aimed at promoting high-return HNFEs and creating out-country remittance employment opportunities for the low income households, making local institutions more effective, and increasing female participation in direct economic activities.
\end{abstract}

Key words: Non-farm income, diversification, developed villages, Bangladesh, income inequality, determinants, censored Tobit regression.

\section{INTRODUCTION}

In a developing rural economy of Bangladesh, where the scope of employments for the increasing labor forces is extremely limited in agriculture (hereinafter farm) sector, the livelihood diversification through NFAs has become a growing reality. The Government of Bangladesh in its national poverty reduction strategy paper has identified the NFS as a "leading sector" in the rural economy. But in practice the NFS is not getting due attention like the farm sector. The portfolio of NFAs for a household is decided on its access to public/private, physical, financial, human and social capitals/assets. However, the promotion of NFAs is not necessarily consonant with improvement in the income distribution.

The question of whether NFI increases or decreases overall inequality is an important concern in most of the developing countries across the globe ${ }^{[3]}$. Regarding this issue, there has been a rich literature drawing on a number of developing countries ${ }^{[5,9]}$. As depicted in Table 1, both of them make almost the similar conclusion: the overall impact of NFIs on income distribution is mixed.

Corresponding Author: Mohammad Abdul Malek, Division of Managerial Economics,

The United Graduate School of Agricultural Sciences, Tottori University, Tottori, Japan

Tel: +81-80-3057-3167 
Am. J. of Economics and Business Administration, 1 (2): 141-149, 2009

Table 1: Mixed equity impact of NFI

\begin{tabular}{|c|c|c|c|c|c|}
\hline \multirow[b]{3}{*}{ Quintile } & \multicolumn{5}{|c|}{ Share of NFI in total income (\%) when NFI is: } \\
\hline & \multicolumn{2}{|c|}{ Equity enhancing } & \multicolumn{2}{|l|}{ Neutral } & \multirow{2}{*}{$\begin{array}{l}\text { Inequitable } \\
\text { Ecuador } 1995\end{array}$} \\
\hline & Egypt 1997 & Pakistan 1989 & India 1999 & Ethiopia 1990 & \\
\hline Poorest & 59 & 75 & 32 & 32 & 22 \\
\hline $2^{\text {nd }}$ & 52 & 63 & 39 & - & 37 \\
\hline $3^{\text {rd }}$ & 51 & 36 & 38 & 30 & 37 \\
\hline $4^{\text {th }}$ & 53 & 33 & 39 & - & 46 \\
\hline Highest & 38 & 21 & 31 & 31 & 64 \\
\hline
\end{tabular}

Source: Table $3.1^{[5]}$

In some instances, overall NFI improves equity across household groups. In other cases, they exacerbate inequality. Empirically, no consistent pattern emerges.

In rural Bangladesh context, the relevant previous study concludes that the NFI will become an important force behind worsening income distribution ${ }^{[8]}$. However, the analyses are based on the narrow definition of NFS which does not explicitly consider the remittance incomes and other transfers as separate components of NFI, whereas, such incomes, nowadays, contribute a considerable share of household income. Such underestimation of NFS is not supported by a number of similar studies ${ }^{[5,15]}$. Moreover, the studies in Bangladesh context on the correlates of NFI diversification, based on the narrow definition of the NFS, use nationally representative sample survey ${ }^{[6-8]}$. These studies, in our knowledge, cannot fully explain the real picture of NFS in less poverty prone area (hereinafter, relatively developed area) where the NFAs are relatively developed and diversified in contributing higher NFI share of household income.

In this context, based on the broader definition of NFS, this study attempts to explore the role of NFAs on household income distribution and to analyze the determinants of NFI diversification based on original data collected from a field survey in four villages in a typical developed rural area, namely, Comilla Sadar Upazila, Bangladesh, where the NFAs are relatively developed and diversified. Like other similar studies, we use standard methodology (income inequality Gini decomposition method for exploring the role of NFIs and censored Tobit regression for estimating determinants of NFI diversification). Thus, this empirical study aims to add new insights for the NFS of relatively developed villages in Bangladesh.

\section{MATERIALS AND METHODS}

Defining NFS: As mentioned earlier, we use broader definition of NFS. The rural household workers engaged in a set of earning activities that are not own farm based or off-farm based (except household enterprises in primary farm production of crop, livestock, poultry and fisheries) are included in the $\mathrm{NFS}^{[9]}$. Especially, the local NFS is defined as any earning activity that the workers are performing in the village, other neighboring villages, growth centers or rural town (excluding Municipality at district head quarter and Pouroshova at Upazia head quarter), while retaining the households in the village. In our definition, we include farm wage employments in the local NFS rather farm sector, because the relatively disadvantaged household (landless/land poor) workers cannot work as self-employed in the farm sector; they work mainly either as farm or non-farm day laborers. Based on the relative returns to labor, we classify the local NFAs into two broad groups: Difficult-entry, high return/productivity that leads to high-income employments (hereinafter high-return NFAs) and easy-entry, low return/productivity employments (hereinafter low-return NFAs) that serve only as a residual source of income ${ }^{[8,13]}$. In addition, a good number of absentee household workers are engaged in remittance employments in another place like nonlocal areas of the country for domestic migration (hereinafter in-country) and abroad for international migration (hereinafter out-country) and these remittance employments are considered as separate categories under non-local NFS. Thus, in present study, we include farm wage employments, non-farm self-employments, non-farm wage employments under local NFS and in-country remittance employments and out-country remittance employments under non-local NFS. Hereinafter, sometimes the NFS, NFAs and Non-Farm Employments (NFEs) are interchangeably used.

The concept of income is comprehensive, including income received in kind and in cash. Household income is defined as the sum of net incomes resulted from the engagements of household workers in local and nonlocal NFS and other incomes. Farm income is defined as all net incomes from primary production of household farm enterprises. Non-farm self-employment income is defined as all net incomes from the HNFEs 
(mostly informal in nature) the workers participated in the local secondary and tertiary industries. Farm wage income and non-farm wage income are gross incomes derived from wage employments participated in the locality. Remittance incomes (in-country and outcountry) are net receipts from the household workers employed in-country and out-country. Other incomes include transfers including rental income, pensions, interests, gifts and disadvantaged allowance.

Diversification is generally defined as an increase in the number of household income components. Then, to take into account the contributions of each NFI component mentioned earlier, we define NFI diversification as NFI shares by components of the household income.

Measuring income inequality: The Gini coefficient, as proposed by $\operatorname{Sen}^{[18]}$, shows the degree of inequality in the distribution of household income. However, the Gini coefficients of income components do not have any significant economic meaning. Hence, we measure Pseudo-Gini coefficients for different components of income and thus, the Gini decomposition analysis is conducted to identify the factors contributing to overall income inequality by following the similar procedure as Shorrocks ${ }^{[19]}$ has suggested and Escobal ${ }^{[4]}$ and Hossain et al. ${ }^{[8]}$ have adopted.

Modeling NFI diversification: According to Benjamin et al. ${ }^{[1]}$, De Janvry and Sadoulet ${ }^{[2,3]}$ and Escobal ${ }^{[4]}$, a standard rural household model for determination of income diversification (for either push or pull factors) has the following feature. That is, the household behaves to maximize its utility subject to several constraints, like (a) a cash constraint, (b) production technologies for farming and NFAs, (c) exogenous effective prices for tradables and (d) an equilibrium condition for household workers. First order conditions of this type of model give a system of factor supply and demand functions, which in turn authorizes the determination of labor allocation between farming and NFAs. If time allocation between farming and NFAs has different utility connotations or if there is commuting time related with NFAs, the shadow price of on-farm activity is endogenously determined within the household ${ }^{[11]}$. If so, production and consumption decisions are non-separable and the household characteristics could affect labor allocation decisions. Thus, we have the following form of reduced form equations for the model:

$\mathrm{S}_{\mathrm{ij}}=\mathrm{f}(\mathrm{P}, \mathrm{Z}, \mathrm{V}),(\mathrm{i}=1,2,3, \ldots \ldots, 214:$ Household and $\mathrm{j}=1,2, \ldots 6$ : Income source)
Where:

$\mathrm{S}_{\mathrm{ij}}=$ NFI shares of the household income

$\mathrm{P}=$ Vectors of exogenous input and output prices

$\mathrm{Z}=$ Vectors of different fixed capitals including human capital, physical capital, financial capital and social capital available to the household

$\mathrm{V}=$ Vectors of capitals available to the community

The previous study estimates three local NFI shares equation $^{[7]}$, whereas, our empirical model estimates six NFI share equations to identify determinants for NFI diversification: farm wage income, non-farm selfemployment income, non-farm wage income, incountry remittance income, out-country remittance income and other incomes.

The previous study puts limited focus on adopting explanatory variables ${ }^{[7]}$. However, based on the field experiences and similar recent studies conducted in other developing countries, we consider many important factors at household and community level compared to the previous one. Considering the difficulty of getting reliable information on input and output prices, household farm Terms Of Trade (TOT) measured by ratio of farm products' (that household sales) price to non-farm products' (that household purchases) price and household access to physical capital, financial capital, social capital and so forth are used as dummy variables. Access to capitals/assets is measured in the sense that the households/household workers receive certain capitals/assets when they require during the reference year. Thus, the explanatory variables are as follows: The household level variables include demographics (household head gender 1 if male/hhh_gen, household head age in years/hhh_age, number of household members/hh_size, economically inactive or dependent members/dependents), household number of income sources as an indicator of diversification/income_sources, farm_TOT ( 1 if ratio is greater than 1), human capital (schooling years of household head and its squared/hhh_edu and hhh_edu2, number of male and female working members/ Male_worker and female_worker, number of in-country and out-country remittance earners as indicators of migration human capital, respectively/migration_cap1 and migration_cap2), physical capital (landholdings owned by the household/landholdings), access to formal credit as a proxy for financial capital/access_credit), and social capital (access to Government Organizations/GOs, Non-Government Organizations/NGOs, and rural cooperatives, 1 if yes, as an indicator of structural social capital/access_cerdit; access to friends, relatives, neighbors., 1 if yes, as an indicator of cognitive social capital/acess_frn). 
Table 2: Basic characteristics of Comilla Sadar Upazila 2005-06

\begin{tabular}{ll}
\hline Item & Characteristics \\
\hline Location & $\begin{array}{l}\text { Comilla in the division of Chittagong. } \\
\text { About 100 km southwest of the capital city Dhaka. }\end{array}$ \\
$\begin{array}{l}\text { Literacy level } \\
\text { Level of } \\
\text { Dependency on } \\
\text { farming }\end{array}$ & $\begin{array}{l}\text { Full-time farm households (10\%), part-time farm } \\
\text { households (70\%), full-time non-farm } \\
\text { Modes of transport }\end{array}$ \\
$\begin{array}{l}\text { Connected (20\%) } \\
\text { railway with Dhaka and Chittagong. }\end{array}$ \\
$\begin{array}{l}\text { Rural markets/ } \\
\text { Growth centers } \\
\text { Major trades and } \\
\text { commences }\end{array}$ & $\begin{array}{l}\text { Farm input business, farm products trade and } \\
\text { agro-processing, transport and construction } \\
\text { business, restaurants, handicrafts and cottage }\end{array}$ \\
industries and grocery \\
Others & $\begin{array}{l}\text { Being assigned "Export Processing Zone (EPZ)" } \\
\text { at Comilla. }\end{array}$ \\
\hline Source: Focus group discussion with key informants (2006)
\end{tabular}

Source: Focus group discussion with key informants (2006)

The community level variables are number of rural markets/growth centers within $1 / 2 \mathrm{~h}$ distance from the household/growth_centre, number of GOs, NGOs and rural cooperatives working in the locality/institutions and nature of the village, 1 if agriculture is relatively less developed /village_nature.

Study materials: As described in Table 2, Comilla Sadar Upazila has been purposively selected for the study as a typical case study area of relatively developed rural area of Bangladesh. Comilla Sadar is an Upazila (sub-district) of Comilla District in the Division of Chittagong, Bangladesh located $100 \mathrm{~km}$ southwest of the capital city Dhaka and adjacent to Tripura of Eastern India. It is connected by national highway and national railway with Dhaka and the second most important industrial city Chittagong. Based on the focus group discussion with the key informants, two groups of villages (first group: Where the farm sector is relatively developed in terms of crop yield, technological adoption, cropping intensity and diversity in cultivation; second group: Where farm sector is relatively underdeveloped, but NFS relatively developed) are selected. Then, four villages from two groups of Comilla Sadar Upazila (excluding urban location Pouroshova at Upazia head quarters) are selected randomly so that the case study villages are well represented. The villages are within the $15 \mathrm{~km}$ reach by usual modes of transport (for example, bus, auto rickshaw and rickshaw) from Comilla district head quarters. We find that literacy rate (case study villages' average) is $75 \%$ while the national average is $53 \%$. Farming is relatively mechanized in the case study villages. Farmers produce plenty of rice and many types of vegetables. Household workers are engaged in local NFAs and remittance employments. Major formal employment sources are "Export Processing Zone (EPZ)" at Comilla, GOs, NGOs, commercial banks and private companies in the locality and non-local areas of the country mainly in Dhaka. A good number of households have at least one out-country remittance earner. Many households are engaged in HNFEs. Thus, we find relatively developed farming and moderate NFS (both local and non-local) in the case study villages. Thus, as developed rural area/villages, the case study area is well-justified.

Then, a survey is conducted among the selected 214 households during August-September 2006 to collect detail data on participation, time allocation and income earned by their all workers $(\mathrm{N}=442)$ participating in certain economic activities such as household farm enterprises and all NFAs for the reference year 200506. Participation is measured by whether individual worker is taking part in certain economic activities, while time allocation yearly given to those activities indicates the level of participation. We take interview of best informed household members for all relevant data based on a structured questionnaire. The focus of the survey is on the household workers and on how each decides, firstly, whether to participate in any of earning activities (either household farm enterprises or NFAs). Secondly, if individual response for NFAs is yes, the next is asked in which sectors of NFAs, he/she participates full-time or part-time. Thirdly, total hours per year allocated to work in all sectors of NFAs aggregates (or disaggregates) the number of hours, days, weeks and months of work declared by an individual have been inquired. For getting yearly time given to formal sector employments and remittance employments (for both out-country and in-country), in addition to their regular office hours, we inquire their over-time periods and then decide their full working time. Next to get information on household income as defined earlier, after asking household annual expenditure, information on incomes from different components has been inquired. All the pertinent information is collected following recall method. In addition to questionnaire survey, observational methods and four separate focus group discussions with the key informants in the four villages respectively are administered for gathering qualitative and community level information.

\section{RESULTS}

\section{Role of the NFAs:}

Participation, time allocation and income shares: The household workers participate in and earn more income from NFAs than from their farm enterprises 
(Table 3). One of the main reasons is that the landless households constitute a sizeable population (about 20\% for our sample) where the importance of NFAs is inevitable. Compared to the participation (66\%), more labor time (about 93\%) is allocated to the NFAs and more income shares $(87 \%)$ are gained as well. Compared to male, the female participation is extremely lower (17\%) in economic activities as well as NFAs. Of the household income components from the participating NFAs, the non-farm self-employments show the highest share (about 28\%) of total income, followed by non-farm wage employments $(20.3 \%)$, outcountry remittance $(20.1 \%)$ and in-country remittance employments (6\%). Apart from local NFAs, about $16 \%$ household workers participate in remittance employments. The household workers (4\%) participate in in-country remittance employments with GOs, NGOs, commercial banks and private companies mainly in the capital city (Dhaka). The out-country remittance employments $(12 \%)$ where they participate mainly in the Middle East (for example, Saudi Arabia) and Southeast Asia (for example, Malaysia and Singapore) under unskilled and semi-skilled category.

Low Vs high-return local NFAs: We have sharp differences in the household net incomes from highreturn [Mean: Bangladesh Currency/Taka (BDT) 89,324 and SD: BDT 57,347 as of 2005-06, US\$ $1.00=$ BDT 67.08 (GOB, 2006)] and low-return (Mean: BDT 55,254 and SD: BDT 31,451) NFAs. Among local NFAs, about $68 \%$ of the participation is observed in low-return NFAs which typically require no particular education and little/no start-up capital. This is due to the households' landlessness, poor education and credit/cash constraints, on the one hand; and significant entry barriers to high return NFAs and market segmentation, on the other hand. In our study villages, such low-return NFAs are roadside and weekly market vendors, grocery shops/retailers with temporary sheds, mechanics and artisans and rickshaw pullers in the informal self-employed category and construction/mill workers and other unskilled poorly-paid non-farm and farm day-laborers under the wage-employed category. On the contrary, only $32 \%$ of the participation is observed in relatively high-return
NFAs which usually require certain skills, education and capital. For instance, salaried jobs with GOs, NGOs, EPZ and other private companies working in the locality under the wage employed category and wooden and steel furniture manufacturing, farm input and equipment manufacturing, food processing, egg/poultry feed/fish trade, grocery shops/retailers with permanent sheds, pharmacy, hotel and restaurant and information communication services which are creating demand in the locality under self-employed category belong to the high-return local NFAs.

NFI distribution: As depicted in Table 4, among the local NFAs, non-farm self-employment income is almost fairly distributed among the income stratums (from 25$29 \%$ ), except the highest income stratum with a large share of about $38 \%$. This must be true that the lower income stratum households receive more income from low-return non-farm self-employments which virtually require no education and little/no capital and vice versa. The higher income stratum households (III-V) do not receive any income from farm wage employments. The reason is that only landless household workers participate in this category. The non-farm wage employment and incountry remittance incomes are not fairly distributed among the income stratums. The reason may be that the lowest two stratum households receive income from lowreturn non-farm day laborers category both in the locality and other areas of the country, whereas, the other higher stratums receive from local formal sector employments which require a certain level of education and skills. The out-country remittance income is fairly distributed among the middle income stratums (II to IV) at $24-25 \%$ range, whereas 11 and $38.5 \%$ for the lowest and highest income stratums, respectively. It is to mention that the highest income households do not receive income from in-country remittance employments rather receive more income from out-country remittance and local non-farm self-employments. Our study findings suggest that the higher income stratum households are more diversified in relatively skilled out-country migration and local high return NFAs. Conversely, the lower income stratums households are more diversified by relatively low-return NFAs.

Table 3: Participation, time allocation and income share by activities in Comilla Sadar Upazila 2005-06 (N = 442)

\begin{tabular}{lccr} 
Activities & Participation $(\%)$ & Time allocation $(\%)$ & Income share $(\%)$ \\
\hline Farm enterprises & 34.4 & 6.5 & 12.8 \\
NFAs as a whole & 65.7 & 93.4 & 87.4 \\
Farm wage employments & 8.6 & 12.8 & 5.1 \\
Non-farm self-employments & 20.8 & 18.8 & 27.7 \\
Non-farm wage employments & 20.2 & 18.1 & 20.3 \\
In-country remittance employments & 4.2 & 20.0 & 5.7 \\
Out-country remittance employments & 11.9 & 23.7 & 20.1 \\
Other incomes &.. & 8.5 \\
Total & 100.0 & 100.0 & 100.0 \\
\hline
\end{tabular}

Source: Filed survey (2006) 
Am. J. of Economics and Business Administration, 1 (2): 141-149, 2009

Table 4: Household income distribution by quintile in Comilla Sadar Upazila 2005-06 (unit: \%)

\begin{tabular}{|c|c|c|c|c|c|c|c|c|}
\hline \multirow[b]{2}{*}{ Quintile (income range) } & \multicolumn{2}{|c|}{ Self-employment income } & \multicolumn{2}{|c|}{ Wage employment Income } & \multicolumn{2}{|c|}{ Remittance income } & \multirow{2}{*}{$\begin{array}{l}\text { Other } \\
\text { incomes } \\
(\mathrm{g})\end{array}$} & \multirow{2}{*}{$\begin{array}{l}\text { Total } \\
\text { NFI } \\
(b+c+d+ \\
e+f+g)\end{array}$} \\
\hline & $\begin{array}{l}\text { Farm } \\
\text { (a) }\end{array}$ & $\begin{array}{l}\text { Non-farm } \\
\text { (b) }\end{array}$ & $\begin{array}{l}\text { Farm } \\
\text { (C) }\end{array}$ & $\begin{array}{l}\text { Non-farm } \\
\text { (d) }\end{array}$ & $\begin{array}{l}\text { In- country } \\
\text { (e) }\end{array}$ & $\begin{array}{l}\text { Out-country } \\
\text { (f) }\end{array}$ & & \\
\hline $\mathrm{I}\left(\mathrm{BDT}^{@} 20,700-116,157\right)$ & 17.0 & 25.0 & 12.0 & 30.0 & 3.0 & 10.6 & 2.9 & 83.0 \\
\hline II (BDT 161,57-211,614) & 10.6 & 26.9 & 1.9 & 18.1 & 10.1 & 25.1 & 7.3 & 89.4 \\
\hline III (BDT211,614-307,071) & 15.6 & 29.1 & 0.0 & 5.5 & 7.8 & 23.9 & 18.1 & 84.4 \\
\hline IV (BDT307,071-402,528) & 9.0 & 24.9 & 0.0 & 15.1 & 4.9 & 25.0 & 21.2 & 91.0 \\
\hline V (BDT402,528-497,985) & 6.5 & 37.8 & 0.0 & 6.9 & 0.0 & 38.5 & 10.3 & 93.5 \\
\hline Average (BDT 107,337) & 14.8 & 26.2 & 9.7 & 25.8 & 4.7 & 13.9 & 4.8 & 86.9 \\
\hline
\end{tabular}

Source: Field Survey 2006. Note: ${ }^{\circledR}$ As of 2005-06, US $\$ 1.00=$ BDT (Bangladeshi Taka) 67.08

Table 5: Income inequality decomposition by income components in Comilla Sadar Upazila 2005-06 (gini index)

\begin{tabular}{|c|c|c|c|c|}
\hline Income Components & Gini & Pseudo-Gini & Contribution (\%) & Gini decomposition \\
\hline Farm enterprises & 0.6358 & 0.2894 & 9.77 & 0.2894 \\
\hline Farm wage employments & 0.8820 & -0.1882 & -2.43 & -0.0163 \\
\hline Non-farm self-employments & 0.7355 & 0.3968 & 27.45 & 0.0820 \\
\hline Non-farm wage employments & 0.7305 & 0.1743 & 9.15 & 0.1512 \\
\hline In-country remittance employments & 0.9407 & 0.5312 & 8.18 & 0.0032 \\
\hline Out-country remittance employments & 0.8304 & 0.6127 & 31.96 & 0.0246 \\
\hline Other incomes & 0.8841 & 0.7232 & 15.92 & 0.0015 \\
\hline Total & 0.3871 & 0.3871 & 100.00 & \\
\hline
\end{tabular}

Source: Field survey 2006.

To examine the impact of NFIs on household income distribution, first we calculate Gini and pseudoGini coefficients for household income and for each of the income components (Table 5). Gini coefficients are calculated using all households, for which a particular income component is available, while pseudo-Gini coefficients are calculated for the full sample. According to Shorrocks, we decompose the Gini coefficients of household income into its factor components ${ }^{[19]}$. The decomposition rule considers the relative importance of each income component, the pattern of inequality of each income component (measured by the pseudo-Gini coefficient) and the correlation between each income component and household income.

According to values of pseudo-Ginis, all unearned income components (remittance employments and other incomes) and non-farm self-employments are more unevenly distributed than the household income, while the incomes from farm self-employments and non-farm wage employments are less unevenly distributed. Though remittance incomes, other incomes (transfers) and non-farm self-employment income are relatively unevenly distributed, these incomes do not appear to favor the poor. It is because the majority of the poor do not have access to these employments.

Determinants of NFI diversification: As mentioned earlier, in order to analyze determinants of NFI diversification, we estimate NFI shares of household income as endogenous variables for all of six NFI share equations. Since some households have zero income shares from some components due to not participating or not gaining, these endogenous variables have some censored data. Accordingly, the estimated method here is censored Tobit regression. As shown in Table 6, the results for farm wage employment income and incountry remittance income share equations are not reported, since running censored Tobit regression in this case is not successful. It is because this particular variable has extremely large number of left-censored observations (178 and 194 out of 214). Among the rest four equations, non-farm self-employment income share equation is statistically significant at $10 \%$ level, while the other three equations are significant at $1 \%$ level. From the statistically significant variable coefficients of the income share equations, several observations can be summarized.

Landholdings are found to be positively associated with non-farm self-employment income. Implication may be that in a developed rural area, landholdings are important not only for farming, but also for promoting HNFEs, because, it may work for accumulating their financial capitals. The non-farm self-employment income is negatively associated with household head education. The reason may be that the HNFEs where household workers usually participate are mostly informal in nature where education is not so important. The negatively significant coefficient of out-country migration capital for non-farm self-employment income is self-evident, however, plausibly it may suggest the fact that the remittance income received is not being utilized in household productive investment, for example, in HNFEs. 
Am. J. of Economics and Business Administration, 1 (2): 141-149, 2009

Table 6: Determinants of NFI diversification in Comilla Sadar Upazila 2005-06 (endogenous variables: NFI shares: Results from censored Tobit estimation $(\mathrm{N}=214)$

\begin{tabular}{|c|c|c|c|c|c|}
\hline Explanatory variables & $\begin{array}{l}\text { Farm wage } \\
\text { income share }\end{array}$ & $\begin{array}{l}\text { Non-farm self } \\
\text { employment } \\
\text { income share }\end{array}$ & $\begin{array}{l}\text { Non-farm wage } \\
\text { employment } \\
\text { income share }\end{array}$ & $\begin{array}{l}\text { Out country } \\
\text { remittance } \\
\text { income share }\end{array}$ & $\begin{array}{l}\text { Other } \\
\text { income share }\end{array}$ \\
\hline Hhh_gen & $-0.515(0.634)$ & $0.446(0.416)$ & $0.257(0.410)$ & $-0.143(0.194)$ & $-0.148 *(0.089)$ \\
\hline Hhh_age & $-00.039(000.081)$ & $00.050(000.063)$ & $-00.078(000.065)$ & 00.029 (000.054) & $0.047 * * *(0.019)$ \\
\hline Hhh_edu & $-0.354(0.354)$ & $-0.133 * *(0.061)$ & $0.421 * * *(0.151)$ & $0.282 * *(0.131)$ & $0.084 *(0.050)$ \\
\hline Hhh_edu2 & $-0.631(0.721)$ & $(\ldots)$ & $-0.182(0.153)$ & $-0.157(0.127)$ & $-0.079(0.049)$ \\
\hline Size & 10.63(40.31) & $-0.005(0.069)$ & $0.505(0.606)$ & $-0.228(0.382)$ & $-0.181(0.159)$ \\
\hline Male_worker & $-0.604(10.885)$ & $0.001(0.075)$ & $-0.70(0.256)$ & $0.155(0.161)$ & $-0.048(0.068)$ \\
\hline Female_worker & $-0.225(0.845)$ & $(\ldots)$ & $-0.083(0.125)$ & $0.042(0.084)$ & $0.008(0.035)$ \\
\hline Dependents & $-10.534(30.481)$ & $(\ldots)$ & $-0.340(0.494)$ & $0.209(0.317)$ & $0.175(0.131)$ \\
\hline Income_source & $0.270^{* *}(0.115)$ & $0.105(0.071)$ & $0.064(0.069)$ & $-0.070(0.052)$ & $0.119 * * *(0.024)$ \\
\hline Landholdings & $-10.946 * * *(0.754)$ & $0.119 * *(0.060)$ & $-0.364 * * *(0.139)$ & $-0.068^{*}(0.036)$ & $0.091 * * *(0.017)$ \\
\hline Migration_cap1 & $-0.097(0.129)$ & $(\ldots)$ & $-0.104 *(0.058)$ & $-0.066(0.054)$ & $-0.020(0.018)$ \\
\hline Migartion_cap2 & $-0.150(0.121)$ & $-0.202 * * *(0.072)$ & $-0.288 * * *(0.080)$ & $0.467 * * *(0.049)$ & $-0.021(0.021)$ \\
\hline Farm_TOT & $-0.989 * * *(0.273)$ & $-0.046(0.125)$ & $0.133(0.119)$ & $0.060(0.097)$ & $-0.002(0.038)$ \\
\hline Access_credit & $-0.220(0.277)$ & $-0.117(0.155)$ & $0.122(0.153)$ & $0.124(0.118)$ & $0.001(0.047)$ \\
\hline Access_org & $-0.004(0.270)$ & $-0.026(0.156)$ & $0.045(0.148)$ & $-0.081(0.116)$ & $0.001(0.047)$ \\
\hline Access_frn & $-0.352(0.223)$ & $-0.111(0.128)$ & $0.147(0.124)$ & $-0.139(0.101)$ & $0.083 * *(0.038)$ \\
\hline Growth_centre & $0.701(10.279)$ & $-0.260(0.704)$ & $0.015(0.727)$ & $-0.027(0.564)$ & $-0.742 * * *(0.227)$ \\
\hline Institutions & $-0.316(0.273)$ & $0.144(0.141)$ & $0.033(0.148)$ & $-0.114(0.103)$ & $0.164 * * *(0.044)$ \\
\hline Village_nature & $0.548(10.156)$ & $-0.199(0.616)$ & $0.129(0.643)$ & $-0.121(0.513)$ & $-0.638 * * *(0.197)$ \\
\hline Constant & $-0.863(0.671)$ & $-0.407(0.417)$ & $-0.539(0.409)$ & $-0.194(0.210)$ & $-0.005(0.090)$ \\
\hline Log likelihood & -620.2300 & -1660.2600 & -1420.5600 & -450.4000 & -150.1200 \\
\hline LR Chi2 & 940.8600 & 220.9400 & 700.9100 & 1810.0500 & 1210.0400 \\
\hline Prob> chi2 & 0.0000 & 0.0854 & 0.0000 & 0.0000 & 0.0000 \\
\hline $\begin{array}{l}\text { Left censored } \\
\text { obs at }<=0\end{array}$ & 178 & 121 & 126 & 161 & 148 \\
\hline
\end{tabular}
Source: Field survey 2006. Notes: (1) Numbers in parenthesis are standard errors. (2) Statistical significance: *** at 1\%, **at 5\%, * at 10\%
levels, respectively. (3) Variables are standardized. (4) For the non-farm self-employment equation, variables indicated by the parenthesis (...) are not considered

As described before, the lowest two stratum households receive income relatively more from lowreturn non-farm wage employments, but regression results suggest that the non-farm wage employment income share is highly positively associated with household head education. These results seem to be contradictory, but reasonable in the sense that the share of income from high-return non-farm wage employments where education is the prerequisite is much higher than that of income from low-return counterpart where education is not required for the entire sample. This explanation may be acceptable, as because another similar study finds male education as a positively significant determinant for relatively highreturn NFEs, but not for low-return counterpart ${ }^{[12]}$. The landholdings are negatively associated with non-farm wage income. As the land poor households have poor financial, human as well migration capitals, they are most likely to earn income from low-return non-farm wage employments, for example, non-farm day laborers. The households with migration capital (both in-country and out-country) are less likely to earn income from local non-farm wage employments.

Household gender, education and male workers are particularly important for out-country remittance income. Gender of household head (1 if male) variable has a special meaning to income share equations especially for other incomes (transfers). It may be true that due to migrate for out-country remittance employments the households become female headed households and thus they have a tendency to receive more income from remittance and other transfers. The households with working members (both male and female) are less likely to receive unearned incomes. Household head age, multiple income sources, landholdings, institutions working in the locality are positively associated with other incomes, while outcountry migration capital, farms TOT, access to credit are negatively with other incomes.

The rural cooperatives work relatively better in the case study villages compared to other rural locations of the country; however, the results do not find any significant impact of social capital variables (access to organization and access to relatives, friends and neighbors) on local NFI shares as expected. The implication is that the social capital that is being formed by rural cooperatives in the case study villages is not taking significant role in NFI diversification. Access to formal credit has also no significant impact on NFI diversification, though a good number of nationalized commercial banks, micro-finance NGOs and 
cooperatives are working in giving credits in the case study villages. The reason might be that the local formal credit providers cannot meet the business demands of the locality. This study also does not find any significant impact of community variables except institutions for other incomes (transfers).

\section{DISCUSSION}

Based on the broader definition of the NFS, this study adds some new insights about the sectoral role both in income diversification and income distribution in a relatively developed rural area of Bangladesh. In addition to local NFS, the analyses explicitly focus on the role of remittance incomes and other transfers. We use income inequality Gini decomposition method for exploring the role of NFIs and censored Tobit regression for estimating determinants of NFI diversification. Analyses are done based on an original field survey data.

Findings regarding the higher participation of household workers in NFAs compared to the farm enterprises in terms of participation, time allocation, income share and return (income share/participation ratio) are consistent to the findings from other similar studies conducted in South Asia ${ }^{[6-9,12-14,16]}$. Of the household income components, the non-farm selfemployments show the highest share, however, participation in out-country remittance employment receive higher return. In terms of dominance, we can find that the NFS rather than farm sector, local lowreturn NFAs rather high-return NFAs, the local NFS rather than non-local NFS, the out-country remittance employments rather than the in-country remittance employments are important. Thus, there is growing importance of the NFI to rural food/income security ${ }^{[17]}$.

The previous study finds that household income is fairly unequally distributed ${ }^{[8]}$, whereas our study is evidence supporting the poor distribution of NFI especially for low-income households. However, the income inequality decomposition results add some additional insights: for example, the out-country remittance employments and the non-farm selfemployments (intuitively, high-return HNFEs) are the largest contributors to income inequality, explaining $60 \%$ of the household income. It is followed by other unearned components (16\%), own-farm production $(10 \%)$, non-farm wage employments $(9 \%)$ and incountry remittance employments (8\%). The farm wage employments alone contribute to reducing income inequality $(-2.4 \%)$.

The previous study finds landholdings, education, household composition variables, among others, as the key determinants of NFI diversification. However, In addition to local NFS, our econometric results give us several important insights for non-local remittance (out-country) and other incomes (transfers): Landholdings are important not only for farm enterprises but also for accumulating financial capitals of HNFEs. The remittance income received might not be utilizing in household productive investment, for example, HNFEs. The share of income from high-return non-farm wage employments where education is the prerequisite is much higher than that of income from low-return counterpart where education is not required. As the land poor households have poor financial, human as well as migration capitals, they are most likely to earn income from lowreturn non-farm wage employments. Household gender, education and male workers are particularly important for out-country remittance income. The female labor forces have a lower tendency to participate in direct economic activities. The households with working members (both male and female) are less likely to receive unearned incomes. Access to social capital and formal credit is playing not significant role in NFI diversification neither for local nor for non-local NFS.

\section{CONCLUSION}

The NFAs are undoubtedly no longer "marginal" in the case study villages. Despite having the greater role of the NFS in income diversification and increasing household income, the NFI components do very little or nothing to reduce income inequality in a developed rural locality of Bangladesh. Moreover, further unevenly access to local high return non-farm selfemployments and out-country remittance employments would actually aggravate the income distribution. Lower extent of local high-return HNFEs is a reality and landholding is crucially important for financing such HNFEs. For high-return non-farm wage employments and out-country remittance incomes, where the low-income households have limited access, education is particularly important. Participation of female in direct economic activities is negligible. Social capital and local institutions are not significantly active in promoting either local or non-local NFS. The future NFS development strategy, thus, should be aimed at promoting high-return HNFEs and creating outcountry remittance employment opportunities for the low income households, making local institutions more effective, and increasing female participation in direct economic activities. 


\section{ACKNOWLEDGEMENT}

We, the authors, are grateful to the survey participants in four villages from Comilla Sadar Upazila who provided valuable information and data for this study. We are particularly acknowledged to the Research Division and Comprehensive Village Development Program (CVDP) of the Bangladesh Academy for Rural Development (BARD), Comilla, for its support in collecting data from the villages.

\section{REFERENCES}

1. Benjamin, Catherine, Corsi, Alessandro and Guyomard Herve, 1996. Modeling labor decisions of French agricultural households. Applied Econ., 28: 1577-1589. DOI: 10.1080/000368496327552

2. De Janvry, A. and A.E. Sadoulet, 1995. Quantitative Development Policy Analysis. Johns Hopkins, Baltimore.

http://openlibrary.org/b/OL1096786M/Quantitative _development_policy_analysis

3. De Janvry, A. and A.E. Sadoulet, 2001. Income strategies among rural households in Mexico: The role of off-farm activities. World Dev., 29: 467-480. DOI: $10.1016 / \mathrm{S} 0305-750 \mathrm{X}(00) 00113-3$

4. Escobal, J., 2001. The determinants of non-farm income diversification in Rural Peru. World Dev., 29: 497-508. DOI: 10.1016/S0305-750X (00)00104-2

5. Haggleblade, S., P. Hazell and T. Reardon, 2009. Transforming the Rural non-farm Economy: Opportunities and Threats in the developing World. IFPRI Issue Brief 58. http://www.ifpri.org/sites/default/files/publications/ ib58.pdf dated 17 September 2009

6. Hossain, M., 2004. Rural non-farm economyevidence from Household Surveys. Econ. Political Weekly, 39: 4053-4058.

7. Hossain, M., 2005. Growth of the rural non-farm economy in Bangladesh: Determinants and impact on poverty reduction. Proceedings of International Conference on Titled Rice is Life: Scientific Perspectives for the 21st Century, International Rice Research Institute, Metro Manila, Philippines, pp: 436-439. http://www.irri.org/publications/wrrc/wrrcPDF/ses sion14-06.pdf dated 17 September 2009

8. Hossain, M., B. Sen and H.Z. Rahman, 2000. Growth and distribution of rural income in Bangladesh: analysis based on panel survey data. Econ. Pol. Weekly, 35: 4630-4637.

9. Lanjouw, J. and P. Lanjouw, 2001. The rural nonfarm sector: Issues and evidences from developing countries. Agric. Econ., 26: 1-23. DOI: 10.1111/j.1574-0862.2001.tb00051.
10. Lanjouw, P., 1999. Rural non-agricultural employment and poverty in Ecuador. Econ. Dev. Cult. $\quad$ Change, 48: 91-122. http://ideas.repec.org/a/ucp/ecdecc/v48y1999i1p91 -122.html dated 17 September 2009

11. Lopez, R., 1986. Structural Models of the farm Household that Allow for Interdependent Utility and Profit Maximizing Decisions. In: Agricultural Household Models, Extensions, Application and Policy, Singh, I., L. Squire and J. Strauss (Eds.). World Bank and Johns Hopkins, Baltimore, ISBN: 0801831490, pp: 306-325.

12. Malek, Mohammad Abdul and Usami, Koichi 2008. Determinants of non-farm employments in rural Bangladesh: A case of Comilla Sadar Upazila. Proceeding of the Bangladesh in the 21st Century: The 2008 Harvard Conference Papers on Economics and Finance, University Press Limited, Dhaka, Forthcoming.

13. Micevska, Maja, Rahut and Dil Bahadur, 2007. Rural non-farm employment and incomes in the Eastern Himalyayas. http://www.cuvillier.ch/assets/mime/UTQ3ZXHPIi umJEs5Bm-

VodqUDmJIaCqSkdAd1orc9VQTouEut/38672703 17.pdf

14. Mishra, D.K., 2007. Rural non-farm employment in Arunachal Pradesh- Growth, Composition and Determinants. NLI Research Studies Series 05/2007, V.V. National Labor Institute, Delhi. http://www.vvgnli.org/publication/075-2007.pdf

15. Naude, A.Y. and J.E. Taylor, 2001. The determinants of non-farm activities and incomes of rural households in Mexico with emphasis on education. World Dev., 29: 561-572. DOI: 10.1016/S0305-750X(00)00108-X

16. Premeratne, S.P. and S.M.P. Senanayake, 2004. Access to rural non-farm economic activities: Results from a field study in Sri Lanka. Indian J. Agric. Econ., 59: 787-797.

17. Reardon, T., K.G. Stamoulis, A. Balisacan, M.E. Cruz, J. Berdegue and B. Banks, 1998. Rural non-farm income in developing countries. Paper prepared for the special chapter of the 1998 State of Food and Agriculture, Food and Agricultural Organization, Rome. http://www.fao.org/docrep/w9500e/w9500e12.htm \#P12-01

18. Sen, A.K., 1997. On Economic Inequality. Clearendon Press, Oxford, ISBN: 019829297X, pp: 24-46.

19. Shorrocks. A.F., 1983. The impact of income components on the distribution of family incomes. Q. J. Econ., 97, pp. 311-326. 